\title{
Bilateral injury of the superior longitudinal fasciculus in a patient with Balint syndrome
}
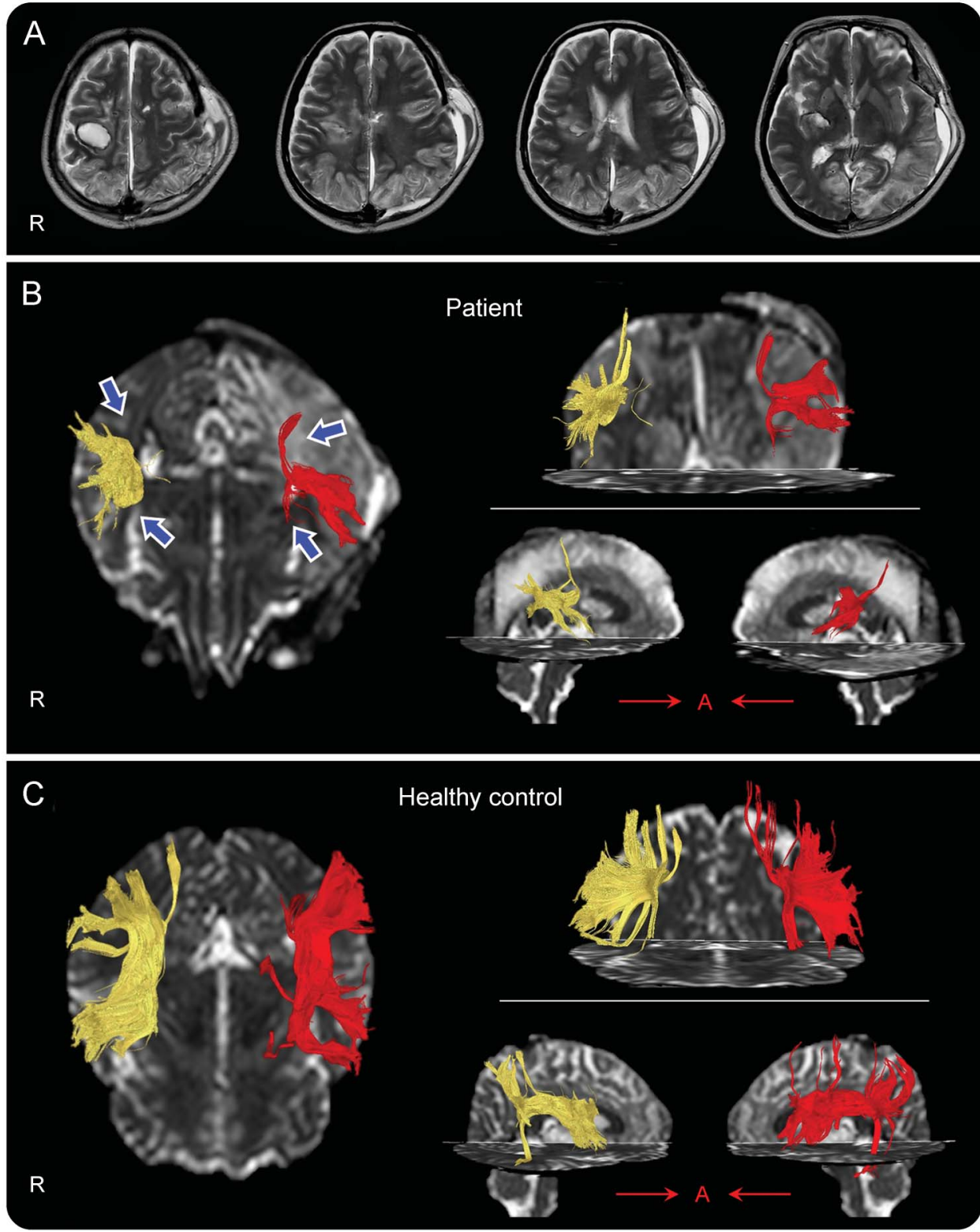

(A) T2-weighted brain MRI at 4 weeks after onset shows leukomalactic lesions in both fronto-parieto-temporo-occipital lobes. (B) Diffusion tensor tractography (DTT) of the patient. On 4-week DTT, both ends of the superior longitudinal fasciculus are discontinued in both hemispheres. (C) DTT of a normal control (50-year-old woman).

A 51-year-old, right-handed woman had a hemorrhage involving the right putamen with intraventricular spread, and underwent extraventricular drainage (right frontal approach) and decompressive craniectomy. She had the triad of Balint syndrome (simultanagnosia, ocular apraxia, and optic ataxia). ${ }^{1,2}$ She also showed quadriparesis and severe cognitive impairment. 
Diffusion tensor imaging data were acquired at 4 weeks after onset; tractography showed that both ends of the superior longitudinal fasciculus (SLF) were interrupted in both hemispheres (figure).

We hypothesize that bilateral injury of the SLF in our patient was the main mechanism of Balint syndrome. ${ }^{1}$

Sung Ho Jang, MD, Chul Hoon Chang, MD, Young Jin Jung, MD, Jeong Pyo Seo, PhD

From the Department of Physical Medicine and Rehabilitation (S.H.J., J.P.S.) and Neurosurgery (C.H.C., Y.J.J.), College of Medicine, Yeungnam University, Deagu, South Korea.

Author contributions: Dr. Jang: conceiving and designing the study, funding, data acquisition, manuscript development, and manuscript writing. Dr. Chang: participated in the design of the study and collection of data. Dr. Jung: participated in the design of the study and collection of data. Dr. Seo: manuscript development, data acquisition, manuscript writing, and manuscript authorization.

Study funding: Supported by a National Research Foundation of Korea grant funded by the Korean government (2015R1A2A2A01004073).

Disclosure: The authors report no disclosures relevant to the manuscript. Go to Neurology.org for full disclosures.

Correspondence to Dr. Seo: raphael0905@hanmail.net

1. Bogousslavsky J, Caplan LR, eds. Stroke Syndromes, 2nd ed. Cambridge: Cambridge University Press; 2001.

2. Hollinger P, Zenhausern R, Schroth G, Mattle HP. MR findings in Balint's syndrome, following intrathecal methotrexate and cytarabine therapy in adult acute lymphoblastic leukemia. Eur Neurol 2001;46:166-167.

\section{Get Connected. Stay Connected.}

Connect with the American Academy of Neurology's popular social media channels to stay up-todate on the latest news and breakthroughs in neurology, and network with peers and neurology thought leaders. Visit $A A N$.com/Connect.

\section{Subspecialty Alerts by E-mail!}

Customize your online journal experience by signing up for e-mail alerts related to your subspecialty or area of interest. Access this free service by visiting Neurology.org/site/subscriptions/etoc.xhtml or click on the "E-mail Alerts" link on the home page. An extensive list of subspecialties, methods, and study design choices will be available for you to choose from—allowing you priority alerts to cutting-edge research in your field!

\section{Translate Today's Discoveries into Tomorrow's Clinic at 2017 Breakthroughs in Neurology Conference}

Get a year-in-review of the latest science and education while earning up to $27 \mathrm{CME}$-with 11.25 qualifying for self-assessment CME—at the 2017 Breakthroughs in Neurology Conference, set for January 13-16 at the beautiful Sheraton Grand at Wild Horse Pass. Secure your spot today: AAN.com/view/breakthroughs. 


\section{Neurology}

\section{Bilateral injury of the superior longitudinal fasciculus in a patient with Balint syndrome}

Sung Ho Jang, Chul Hoon Chang, Young Jin Jung, et al. Neurology 2016;87;1519-1520

DOI 10.1212/WNL.0000000000003185

\section{This information is current as of October 3, 2016}

\section{Updated Information \& Services}

References

Citations

Subspecialty Collections

Permissions \& Licensing

Reprints including high resolution figures, can be found at: http://n.neurology.org/content/87/14/1519.full

This article cites 1 articles, 0 of which you can access for free at: http://n.neurology.org/content/87/14/1519.full\#ref-list-1

This article has been cited by 1 HighWire-hosted articles: http://n.neurology.org/content/87/14/1519.full\#\#otherarticles

This article, along with others on similar topics, appears in the following collection(s):

Intracerebral hemorrhage

http://n.neurology.org/cgi/collection/intracerebral_hemorrhage

Neglect

http://n.neurology.org/cgi/collection/neglect

Information about reproducing this article in parts (figures,tables) or in its entirety can be found online at:

http://www.neurology.org/about/about_the_journal\#permissions

Information about ordering reprints can be found online:

http://n.neurology.org/subscribers/advertise

Neurology ${ }^{\circledR}$ is the official journal of the American Academy of Neurology. Published continuously since 1951, it is now a weekly with 48 issues per year. Copyright @ 2016 American Academy of Neurology. All rights reserved. Print ISSN: 0028-3878. Online ISSN: 1526-632X.

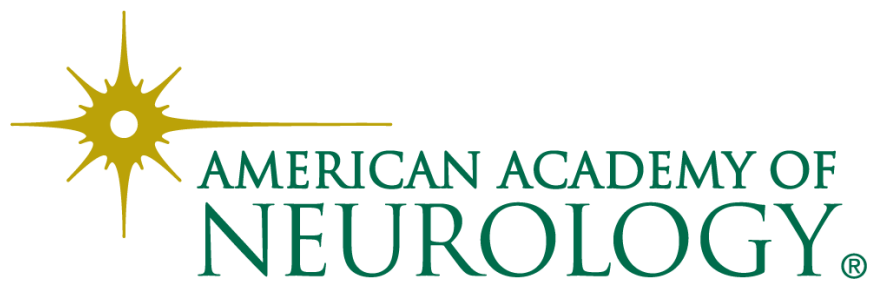

